\title{
Social Media and the Electoral Politics of India
}

\author{
Dikshita Buragohain
}

\begin{abstract}
: the use of social media has become a new strategy for the political parties during election campaign. The social media is playing a significant role in changing people's perception towards politics, politicians and modes of political participation. The advent of budget smart phones and affordable data packages has given greater scope for people to voice their opinion on social and political issues. With accounts in every social media platforms, the political parties and their leaders are using it as a new space to mobilize people. Since 2014 Lok Sabha election, the social media is playing a pro-active role in deciding which party will win the election. While this has led to increased speed of spread of information and news, it has also left the ordinary people vulnerable to fake news and exposed them to 'hate speech'. One hand, the social media is making Indian democracy more inclusive thereby giving citizens the space to express their opinion. On the other hand, it is also creating a gap between different communities by spreading fake news and propaganda. Hence, there should be some kind of restrictions to using it. The misuse can lead to chaos and instability in a democracy.
\end{abstract}

Keywords: internet, social media, political party, election, campaign

\section{INTRODUCTION}

As the world hails the maturity of democracy in India, the noticeable presence of social media in influencing the voters and the ability of that medium to give a space to unknown individuals of the country to express their opinions, by has now become a reality. The social media is playing a significant role in changing people's perception towards politics, politicians and modes of political participation. With the changing nature of politics and political parties, the social media provides a new space to reaching out the masses in every corner of the society.

Since 2014 Lok Sabha elections, the political parties have invested heavily in digital political campaigning. Those political parties that leveraged social networking sites (SNS) to interact with their supporters have turned out to be the most successful in electoral terms. With the increasing number of smart phones in the market and the affordable data packages, it is become easier for the public to use social media platforms. As internet penetration deepens, online social networks and messaging apps are becoming accessible to more and more Indians across communities and geographic locations.

Revised Manuscript Received on November 30, 2019.

* Correspondence Author

Dikshita Buragohain*, Research Scholar, Department of Political Science, Gauhati University.

(C) The Authors. Published by Blue Eyes Intelligence Engineering and Sciences Publication (BEIESP). This is an open access article under the CC-BY-NC-ND license http://creativecommons.org/licenses/by-nc-nd/4.0/
The user friendly interface of social media applications such as WhatsApp, Twitter, Facebook, Instagram and YouTube has made this new method of communication accessible to different sections of the society. propagate their ideology, mobilize public opinions, set policy agendas, and discredit the opponents.

The consumption of social media platforms makes it necessary to study the potential impact it might have in shaping public opinion and influencing their vote choice. The present study seeks to explore the extent use of social media in the electoral politics of India. The study is based on secondary sources that include book, newspaper, journals etc.

\section{METHODOLOGY}

This paper is a descriptive and analytical one. Attempt has been made to include the details of the facts on the basis of secondary sources like books, articles published in different journals and newspaper.

\section{USE OF SOCIAL MEDIA IN INDIA:}

The use of social media has rapidly grown in India. The advent of budget smart phones and affordable data packages has given greater scope for people to voice their opinion on social and political issues. While this has led to increased speed of spread of information and news, it has also left the ordinary people vulnerable to fake news and exposed them to 'hate speech'. News has become propaganda and public now seems even hungrier to consume such news. Traditional media has now taken a backstage. While the TV media has still managed to hold its own, there is never any doubt that the future lies in smart phone driven content. And yes, Indians have become vociferous consumers.

As the fourth pillar of democracy, the press and its allied mediums is crucial for safeguarding the rights of the people and plays a key role as a 'political watchdog' as it informs the public about political issues, schemes, programmes and bringing about a certain degree of accountability of the ruling class. According to the Time series NES data, the media penetration into Indian society has increased significantly in recent years. The study also shows that apart from the traditional media i.e., television print and radio, the last decade has witnessed the growing influence of the internet and social media platforms such as Facebook, Twitter, Google plus, YouTube, and so on. ${ }^{1}$ While television is believed to have played a major role in moulding public opinion during elections in India for the last two decades, 


\section{Social Media and the Electoral Politics of India}

the surge in internet penetration and the arrival and growth of different kinds of new digital technologies and online social networks such as Facebook, Twitter, WhatsApp, YouTube, Instagram etc. has challenged its dominance somewhat ${ }^{2}$. From just 5.5 million in 2000, Internet users in India are increased to 566 million in December 2018. Among them, rural users comprise 250 million, which was the national total at the time of the 2014 election $^{3}$. Social media users such as Facebook, Twitter and WhatsApp have also seen massive growth. India is the leading country in terms of Facebook users, overtaking the $\mathrm{US}^{4}$. As of November, 2018, Facebook is used by 270 million Indians in the age group of 18-65 monthly ${ }^{5}$. On the other hand, WhatsApp is also leading in the country. In fact, WhatsApp has the largest user market in India with over 230 million monthly active users ${ }^{6}$. Similarly, India has over 34 million active Twitter users. The growth in social media has been triggered by the decline in mobile tariffs and handset prices. Hence, the impact of SNS could be seen in different sphere of life that includes education, healthcare, entertainment, politics, and accessing news. While it has increased the 'space' of peoples' voices, it continues to remain highly unregulated and controlling the same has now become a herculean task for any government.

\section{SOCIAL MEDIA AND THE ELECTORAL POLITICS OF INDIA}

The trend of the use of social media in the politics is visible in every democratic country. Over the years the Indian media landscape has undergone a massive transformation. Needless to mention here that the social media is not just a simple way of connecting family and friends; rather it has metamorphosed into becoming an influential space for political activity and discourse often leading to heated and polarized conversation ${ }^{7}$. Initially, the traditional media used to play a dominant role during election by providing information about issues and debates on elections, policies and programmes of the political parties etc. However, the use of social media including Facebook, WhatsApp, Twitter, Instagram, YouTube etc. has significantly altered the way campaigns are run. Political campaigns involve multiple activities and require various skills which include organizing rallies, designing messages, arranging public speaking events, political advertising, grass-roots mobilization etc. The expansion of social media has not only transformed political communication in India, it has also enabled the political parties and leaders to use different mediums more effectively than before. In other

\footnotetext{
Lokniti CSDS report on Social Media and Political Behaviour, 2019.

3 https://economictimes.indiatimes.com/news/elections/lok-

sabha/india/view-anti-social-media-in-elections2019/articleshow/68821364. cms? from $=\mathrm{mdr}$

IANS, 'India Overtakes US As Facebooks No.1 Users', The Hindu, 14 July 2017 http://www.thehindu.com/sci-tech/technology/internet/india- overtakes-us-as-facebooks-no1-user/article19276683.ece

5 https://www.hindustantimes.com/india-news/whom-can-political-partiesreach-on-facebook-and-why-it-matters/storyQ0SIECJ5xP9B7F0CYlJEYP.html

QOSIECJ5XP9B7F0CYIJ

6 https://www.hindustantimes.com/india-news/political-parties-in-indiaabuse-whatsapp-service-ahead-of-polls-executive/storyBKANYG9qzOEWRf2LjmPD5K.html

${ }^{7}$ Lokniti CSDS report on Social Media and Political Behaviour, 2019.
}

words we can say that social media provides a more easy method to communicate political leaders and political parties with the people across the country.

The political actors have been using social media to mobilize opinion and support, and set public agenda, while the marginalized groups have been using the medium to raise their grievances and put forth their demands ${ }^{8}$. All political parties and their leaders use various social media platforms to spread messages and to micro-target their campaigns. Even the Government has been using different social media platforms to communicate their policies and programmes to the citizens. That means the technology is being used in a big way to understand the citizens as well as influence their choices in a variety of ways.

The first extensive use of social media in elections can be seen in the 2014 Lok Sabha elections. Prime Minister Narendra Modi of Bharatiya Janata Party (BJP) had realized the importance of digital media early and had tried to integrate it in the 2014 Lok Sabha election campaign strategies. The BJP has used the social media platforms as well as mobile phones campaigns widely. The 2014 Lok Sabha elections were tagged as India's first real media election, or at least a "substantially mediatised" one compared to previous polls ${ }^{9}$. Even after assuming office as the Prime Minister, Narendra Modi has not called even a single press conference, which in turn also shows his confidence in his social media outreach to communicate with the people directly ${ }^{10}$.

According to the CSDS study, one sixth of the 230 million India who uses WhatsApp are members of chat groups started by political parties. These groups, apparently used to organize rallies, recruit volunteers, or disseminate campaigns. That is why the 2019 Lok Sabha election is widely expected to be the "WhatsApp elections". WhatsApp is one of the easiest medium to mobilize people with instant messaging through groups. Moreover, most of the new Internet users in India, particularly from small towns and rural areas start their internet activities through WhatsApp.

\section{DISCUSSION: TECHNOLOGY AND INNOVATION AS A MEDIUM OF ELECTION}

\section{CAMPAIGN}

In the last two decades, Indian electorates have been more exposed to the media than ever before. Social media have become an integral part of political communications during election campaigns. Earlier, the political parties and the leaders had to deliver their agenda, policies through traditional media which have a scope to edit it. But now, the leaders can convey their message directly through social media platforms. They could establish a direct connection with the citizens. Therefore, we have witnessed a massive use of social media during election campaigns.

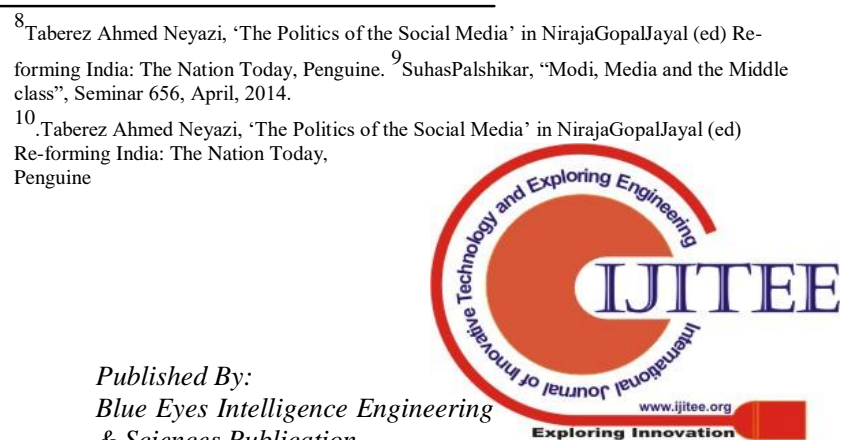

${ }^{8}$ Taberez Ahmed Neyazi, 'The Politics of the Social Media' in NirajaGopalJayal (ed) Reforming India: The Nation Today, Penguine - SuhasPalshikar, "Modi, Media and the Middle class", Seminar 656, April, 2014.

${ }^{10}$.Taberez Ahmed Neyazi, 'The Politics of the Social Media' in NirajaGopalJayal (ed) Re-forming India: The Nation Today, 
It is worth mentioning here that, apart from the personal accounts in various SNS by the political leaders, the political parties have active Information Technology (IT) cell to monitor online activities. They can dispel misinformation or any propaganda deemed detrimental to their interests.

The BJP is the leading political party to use social media platforms the most. The political leaders have personal accounts in every social media platform. The Prime Minister Narendra Modi is one of the most popular political leaders on social media. After winning elections in 2014, Modi tweeted, "India has won, Good days are coming" using Hindi and English language. Some of his opponents and his followers congratulated him on the platform. The response was expected because Mr Modi and his team had used social media in innovative ways to maximize their reach among the young voters during the campaign. The youth constitutes the largest community of voters which is more mobile friendly in nature as compared to the aged. Apart from its leadership, the party has its official page on social media platforms. The state IT cells of the party have between 20 to 30 office bearers depending on the size of the state. Theyhandle day-to-day campaign strategies; generates trending content based on comments by leaders or by attacking opposition. The NaMo app, WhatsApp, Twitter, Instagram Telegram are being used by the party to campaign in the election. One of the major strategy used by the BJP was the more use of regional language than other parties in visual communication. The IT cells operate in a control room-like scenario: observing the opposition's digital strategies, watching TV channels, scouring through newspapers and magazines to track comments by politicians, preparing rebuttles for questions or accusations on social media, editing videos, creating interactive graphics, and minutely monitoring local constituencies to help their candidate's campaign effectively. They also feed party-positive information to a network of thousands of part- time volunteers comprising students, homemakers, IT professionals, entrepreneurs, lawyers and engineers, among others ${ }^{11}$. The party had started different campaign during election like 'Mera Booth Sabse majboot' in February where using hashtag on twitter has been seen. Similarly, in the 'Mera Parivar Bhajpa Parivar' campaign, it has been noticed that the booth level workers across India had uploaded photos on social media with party flags and stickers outside their houses.

While the BJP had the advantage of adopting technology and social media earlier, we are now witnessing a kind of level playing field among different political parties and leaders. Rahul Gandhi, the then Congress President, for instance has become more active on social media since middle of 2017. In April 2018, Rahul had 6.49 million followers on Twitter which has crossed 10 million in 2019. He has a verified Facebook Account too with 2.08 million followers. Besides, the Congress party has established a data analytics department, headed by Praveen Chakraborty, a former invest banker on February.

11 'Hashtag battle: inside the BJP and Congress Social media war rooms', Forbes India, March 27 , 2019, http://www.forbesindia.com/article/poll- vault/hashtag-battle-inside-the-bjp-congress-socialmedia-war-
Chakravarty's appointment was announced through twitter where Rahul Gandi tweeted, "Excited to announce a 'Data Analytics' department under the leadership of Praveen Chakravarty to effectively use 'Big Data'.'This shows the realization in the oldest political party about the role of technology in the campaign strategies to reach potential voters. The department played a key role in the direction and delivery of the 2019 Lok Sabha poll campaign at multiple levels- focus on the Rafale jet deal as a sign of alleged corruption by the senior BJP leadership; the timing of the NYAY income guarantee scheme as medium to persuade the economically weaker sections of the society; and even selection of the candidates in some states- as data provided by the unit was taken as an important guiding factor. ${ }^{12}$ Besides, the Congress party started an app named 'Shakti' in July 2019 to strengthen the Congress ground organization by connecting with workers across every booth, block, town and district. This is congress' internal app of sorts which has connected 65 lakh workers. The workers were asked to register through SMS and their voter card and booth numbers. After they registered, they became registered Shakti members and the Congress had their unique data in system. A GPS enabled app, it maps a worker to his or her booth. It gives them the voters' lists. The workers push the party's message, which is tailor-made for the electorate of the constituency. Regarding the app, chakravarty remarked, "Shakti is not an app. It is a platform. It is a closed platform meant only to connect with Congress workers and we know everything about the people who join It. ${ }^{13 \text { " }}$ the IT cells of the Congress party comprises with 15-20 people who are a mix of party workers and professionals. Apart from 'GharGhar Congress' app and 'Shakti' platform, the INC extensively used WhatsApp, Twitter, Facebook, Instagram, Youtube to experiment with live video formats for publicity, making GIF and memes, used catchy hashtags. Through social media platforms the party draw issue based comparison with BJP highlighting pro-party messages; it attacks government on policy measures and misinformation. With the arrival of online platforms, the increasing polarization and toxic debates with troll armies are also at the forefront. A number of troll armies are supporters of political leaders. The hash tag game and trolling of each other on social media platform has become a common phenomenon now a day. For example, on March 17, when PM Modi prefixed his name with the word 'Chowkidar' (watchman) on twitter, numerous BJP cabinet Ministers, Chief Ministers followed the trend. The PM was possibly countering Congress President Rahul Gandhi's 'Chowkider

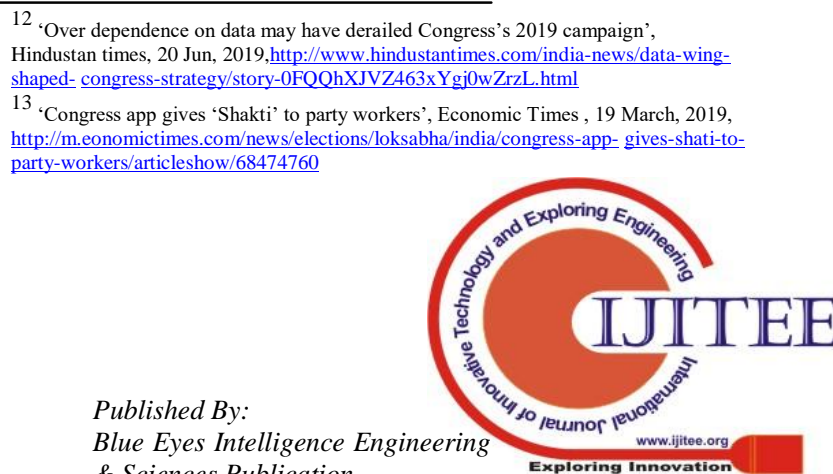

12 'Over dependence on data may have derailed Congress's 2019 campaign', Hindustan times, 20 Jun, 2019,http://www.hindustantimes.com/india-news/data-wingshaped- congress-strategy/story-0FQQhXJVZ463XYgjOWZrzL.htm

13 'Congress app gives 'Shakti' to party workers', Economic Times , 19 March, 2019 http://m.eonomictimes.com/news/elections/loksabha/india/congress-app- gives-shati-toparty-workers/articleshow/68474760 


\section{Social Media and the Electoral Politics of India}

Chor hain' (the watchman is a thief) campaign against him on corruption charges, especially on Rafale deal.

Following it, Twitter was flooded with people adding 'chowkidar' to their names using the hash tag mein bhi chowkidar. It shows BJP's ability to mobilize people on social media platforms.

\section{RESULT AND ANALYSIS}

It is evident that, with the advent of online platforms, the political parties become successful in mobilizing people. The election results show that the use of social media advantages political party to attract voters. From different studies it has been noticed that, social media provides a little advantage to BJP compared to other political parties. As could be expected, given the party's well-funded information technology cell. Both BJP and Congress did better among voters who use social media. Regional parties could not benefit much, with their support amongst high social media exposure dropping considerably compared to voters who don't use social media. However, the Congress did really well in 2019 Lok Sabha elections than 2014 Lok Sabha elections in using social media platform to mobilize the voters in their favor.

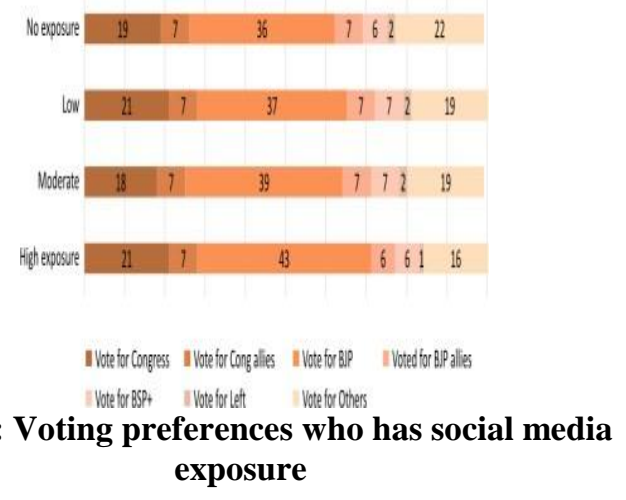

Source: scroll.in

According to CSDS data, high social media use correlates with people being more politicized. For a person with high social media exposure, his chance of attending in election rally were more than twice as high as compared with a person with no exposure. CSDS data shows that while $47 \%$ of people with high social media exposure feel close to the $\mathrm{BJP}$, that figure is only $18 \%$ for the Congress ${ }^{14}$.

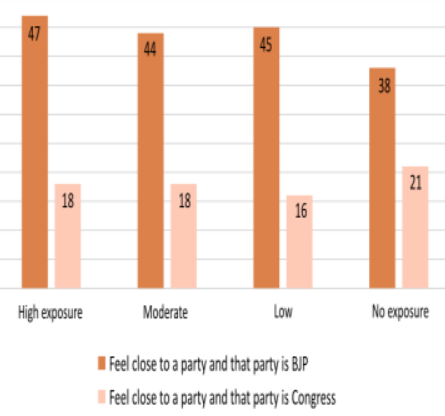

Figure 2: Voters feel close to political parties who has social media exposures

\footnotetext{
14 https://scroll.in/article/927651/in-charts-was-the-influence-of-social- media-on-the-2019-lok sabha-election-exaggerated
}

\section{Source: scroll.in}

Although, on the one hand the democratization of the space, which could be credited to affordable smart phones and cheap internet data packs, must be appreciated and welcomed, but on the other, this massive growth of social media seem to have also become a problem for democracy $^{15}$. With a much higher number of people online and on the immensely popular messaging platform WhatsApp, the scope for these platforms to be abused by the intentional misleading information and manipulation of voters can never be denied. The users who are experiencing and engaging with these mediums for the first time and the ones who are comparatively less educated might be more vulnerable than others (although the educated don't fare too well either in this respect) ${ }^{16}$. Some recent studies have shown that many people are having a hard time differentiating real information and news from made-up and fake stories. There were also reports last year of vested interests using these mediums, especially Facebook and WhatsApp, to spread 'fake news' and tailored content to sway voters. Many of the mob lynching that took place a year ago were also attributed to the spread of fake news on WhatsApp. While political parties have been using the medium to reach out to probable voters with targeted messages, the feature of encryption has also proved helpful to those who want to propagate misinformation and propaganda. It is easier to circulate the Rumours quickly through WhatsApp. Now a day's people can write anything and can get away with it. As more people join Whatsapp the incidents of misusing of the app by spreading misinformation is also growing. The problem is so serious that just before the 2019 LokSabha election, the Election Commission met representatives of social media firms to try to find ways of how content on social networking sites and apps that violated the election code of conduct could be deleted. Although, the companies owning these spaces did step up their efforts to stop misuse and took steps in this direction, it was perhaps a case of doing too little too late with much of the damage to not just democracy but society at large being already done $^{17}$. Due to the misuse of the WhatsApp before and during 2019 LokSabha Polls, the WhatsApp had banned 2 million accounts per month ${ }^{18}$. They have in fact said that there are instances of the platform being misused by the political parties and warned them that it will ban accounts in the run up to the 2019 LokSabha elections. The misuse of social media proves that the freedom without any curbs can be very dangerous. And, precisely, lack of any control in its content has made social media is a highly destructive tool.

\footnotetext{
15 Lokniti CSDS report on Social Media and Political Behaviour, 2019. ${ }^{16}$ Lokniti CSDS report on Social Media and Political Behaviour, 2019. ${ }^{17}$ Lokniti CSDS report on Social Media and Political Behaviour, 2019.

18 'WhatsApp is banning 2 million accounts every month and will ban yours if you do any of these things', India Today, February 7, 2019.

https://www.indiatoday.in/technology/features/story/whatsapp-is-banning- 2-millionaccounts-every-month-and-will-ban-yours-if-you-do-any-of- these-things-1450211-2019-02 $\underline{07}$
} 
Unprincipled elements are being used in social media to carry out slander campaign, misinformation, unrest and violence.

Concerned over the misuse of this mass media tool, the Supreme Court on 25 ${ }^{\text {th }}$ September 2019 observed that technology has taken a 'dangerous turn'. The Supreme Court asked the Centre to appraise it within three weeks of the time frame and to come up with needed guidelines to curb misuse of social media in the country ${ }^{19}$. The SC expressed grave concern over social media platforms not being able to trace the originator of a message or an online content. With the growing activities on social media platforms, it is now become necessary to identify the originators of fake news that triggers violence in the society that has a potential risk to the country's security, or defames individuals.

\section{VII.CONCLUSIONS}

The use of various social media platforms to mobilize people is getting more prominent with more people joining the online platforms. Now, the growing importance of social media in day- to-day life cannot be ignored. With the growing amount of users, the implication of online campaigns is rendering all political parties to integrate social media as a key strategy to mobilize public opinion. The new media has become the fertile ground for the political parties and leaders to manipulate public opinion. At the same time, its negative use can also be seen. The political parties can use the platform to manipulate the voters by providing misinformation. Hence, there should be some kind of restrictions to using it. Otherwise it can have negative impacts in the stability of the society. The misuse can lead to chaos and instability in a democracy.

\section{REFERENCES}

1. Lokniti CSDS report on Social Media and Political Behaviour, 2019.

2. Mahapatra, Sangeeta and Johannes Plagemann (2019): "Polarisation and Politicisation: The Social Media Strategies of Indian Political Parties", GIGA Focus Asia, Number 3, March.

3. Neyazi, Taberez Ahmed (2019): 'The Politics of the Social Media' in NirajaGopalJayal (ed) Re-forming India: The Nation Today, Penguine, pp. 524-536.

4. Palshikar,Suhas (2014): "Modi, Media and the Middle class", Seminar 656, April.

5. Verma, Rahul ,ShreyasSardesai, (2014), "Does Media Exposure Affect Voting Behaviour and Political Preferences in India?" Economic and Political Weekly, Vol XLIX No 39.

6. https://www.cjr.org/the_media_today/india_election_facebook_f ake news.php

7. http://epub.sub.unihamburg.de/epub/volltexte/2019/89510/pdf/gf_asien_1903_en.p df

8. https://thewire.in/politics/amit-shah-bjp-fake-social-mediamessages

9. https://www.theatlantic.com/international/archive/2019/04/india -misinformation-election-fake-news/586123/

10. Ullekh, NP, and Amita Shah (2018), The Pitch Update, in: Open, www.openthemagazine.com/article/politics/the-pitch- update (1 July 2018).

11. Editorial, The Assam Tribune, 26 september 2019.

\section{AUTHORS PROFILE}

Dikshita Buragohain, a PhD. Research Scholar at Department of Political Science, Gauhati University. She has completed M.A. degree in Political Science from Gauhati University. Her research interest includes electoral politics and Indian politics. 